\title{
How Safe is the Water Consumed in Different Parts
}

\section{of Nairobi, Kenya?}

\author{
Kithure Joyce G.N., Nyamu Gideon Waithaka \& Eunice Klee Kitavi \\ Department of Chemistry, University of Nairobi, Kenya
}

\begin{abstract}
Water is very important in human beings because it plays a greater role, in that it keeps the body properly hydrated for brain and body cells functioning among others. In the rural areas water may be supplied through pipes or directly taken from the sources such as Rivers, Oasis and Lakes, while in the urban areas water is mainly supplied in polyethylene terephthalate (PET) plastic made bottles. Heavy metals are among the major products that may lead to water contamination, which should be maintained below the permissible level by the health organizations. This project dealt with the analysis of contaminants in different types of water brands that are consumed in Nairobi County in Kenya. Seven trusted brands of bottled drinking water were obtained from some Supermarkets in Nairobi city and analyzed for heavy metals, which includes; $\mathrm{Sb}, \mathrm{Cr}, \mathrm{Mn}, \mathrm{Pb}, \mathrm{Cd}, \mathrm{Cu}$ and $\mathrm{Zn}$ and the residue levels of physico-chemical parameters including $\mathrm{pH}$, Electrical Conductivity (EC) and Total Dissolved Solids (TDS) were also determined. The heavy metals were analysed using Atomic Absorption Spectrometer (AAS) Spectra AA-10, while the physico-chemical parameters were analysed using the standard methods for the examination of bottled drinking water. The results reviewed that; antimony levels were Below Detectable Limit (DBL) in all the samples, while copper concentration ranged between BDL and $0.05 \pm 0.01 \mathrm{mg} / \mathrm{g}$ in all the samples, which was in the range stipulated by World Health Organization (WHO) and Kenya Bureau of Standards (KEBS) of $0.1 \mathrm{mg} / \mathrm{g}$ and $2.00 \mathrm{mg} / \mathrm{g}$ respectively. Lead concentration residue levels on the other hand ranged between BDL and $0.32 \pm 0.19$ $\mathrm{mg} / \mathrm{g}$ in the seven samples. Cadmium residue levels were Below Detection Limit (BDL) in all the samples analysed in the two projects, while chromium ranged between BDL and $0.66 \pm 0.03$ $\mathrm{mg} / \mathrm{g}$. The concentration of manganese was in the range of BDL and $0.93 \pm 0.53 \mathrm{mg} / \mathrm{g}$, Zinc was not detected in all the samples. Lead, Chromium and Manganese residue levels were all within the limit set by WHO and KEBS in most of the samples, but some of their levels were higher than those standards in only few water samples. The $\mathrm{pH}$ values ranged between $6.72 \pm 0.15$ and $7.32 \pm 0.01$ in all the samples. These values were all within the standard set levels by the health organizations, which are in the range of 6.0 and 9.4. These organizations include, National Environment Management Authority (NEMA), KEBS and WHO. The TDS levels were in the range of $26.80 \pm 0.50 \mathrm{mg} / \mathrm{l}$ and $100.70 \pm 0.08 \mathrm{mg} / \mathrm{l}$, which were well below the set standards set by NEMA, KEBS and WHO of 1,500 mg/l each. On the other hand, the $E C$ was in the range of $74.50 \pm 0.05 \mu \mathrm{S} / \mathrm{cm}$ and $197.70 \pm$ $0.02 \mu \mathrm{S} / \mathrm{cm}$, which was within the range set by NEMA, KEBS and WHO of $25-2,500 \mu \mathrm{S} / \mathrm{cm}, 30-2,500 \mu \mathrm{S} / \mathrm{cm}$ and $26-2,500$ $\mu \mathrm{S} / \mathrm{cm}$ respectively. There is therefore, need for regular monitoring of $\mathrm{pH}$ values of bottled drinking water by the respective water bottlers.
\end{abstract}

Key words: Water, Brands, Contaminants, Pollution and AAS

\section{INTRODUCTION}

$I^{\prime}$ n human life, water is a vital welfare significantly more than food. It has been reported that human being can die after one week without any liquids but can survive for couple of months without food ${ }^{1}$. Water plays a greater role in the body such as regulating body temperature through perspiration; it helps in physiological homeostasis and that it keeps the body properly hydrated among many other roles ${ }^{2}$. This therefore, calls for an increase and continuous drinking water supply. An increase in population need increased water supply, therefore, Nairobi County is among the most populated urban cities in Kenya in sub - Saharan countries. According to World Bank 2015 statistics is that at least 85\% of the urban population has access to safe drinking water. However, this percentage is much lower than that of world average for urban population which is $96 \%{ }^{3}$.

Due to the increasing economic and industrial activities within Nairobi city, her population has tremendously increased up to 47.5 million $^{4}$, which in turn as triggered the supply of clean drinking water in portable bottles to counter the high demand from this populace. Most of these bottles are made of plastic thus raising concern over the levels of contaminants that may have been caused either during their manufacturing process or through piping by the bottlers company. $\mathrm{Sb}, \mathrm{Cd}, \mathrm{Cr}, \mathrm{Cu}, \mathrm{Mn}$ and $\mathrm{Pb}$ and their compounds are the common heavy metals that have been found to be the main contaminants in drinking water which can cause health complications and diseases if consumed at high levels 5 .

\section{1: Statement of The Problem}

The fact that drinking water is a rare asset in most places in the world, some individuals tend to use it without earlier information of its fitness to human utilization. For example, water may contain overwhelming high levels of metals contaminants including; antimony, copper, cadmium, Lead, and chromium. Impacts of substantial metals to human wellbeing are known from the past examinations. It is therefore very crucial to assess the levels of these contaminants in the water consumed in Nairobi County. There is also a need to evaluate the level of the selected heavy metals such as $\mathrm{Zn}, \mathrm{Cr}$, $\mathrm{Cu}, \mathrm{Mn}$, and $\mathrm{Pb}$ and compare them with the set standards permissible by different bodies locally and globally. 


\section{2: General Objective}

The main objective here was to determine the residue levels of selected heavy metals and physico-chemical parameters in bottled drinking water consumed in Nairobi County and compare them with NEMA, KEBs and WHO permissible levels.

\subsection{1: Specific Objectives}

The specific Objectives of this research was to: Determine the levels of heavy metals viz $\mathrm{Sb}, \mathrm{Cd}, \mathrm{Cr}, \mathrm{Mn}, \mathrm{Cu}, \mathrm{Pb}$ and $\mathrm{Zn}$ in seven brands of bottled drinking water obtained from Nairobi, County.

1. Determine the concentrations of $\mathrm{pH}, \mathrm{TDS}$ and Electrical conductivity in the seven brands of bottled drinking water.

2. Compare and contrast the quality of the drinking water consumed in Nairobi County market to the standards set by the international organizations such as NEMA, KEBs and WHO.

\section{MATERIALS AND METHODS}

\subsection{Study Area}

Nairobi is the capital City of Kenya located at the southeastern end of Kenya's agricultural heartland, at approximately $1^{\circ} 9^{\prime} \mathrm{S}, 1^{\circ} 28^{\prime} \mathrm{S}$ and $36^{\circ} 4^{\prime} \mathrm{E}, 37^{\circ} 10^{\prime} \mathrm{E}$. It occupies an area of about $696 \mathrm{~km}^{2}$ and the altitude varies between 1,600 and 1,850 metres above sea level ${ }^{6}$. The western part of Nairobi is on high ground (approximately 1700-1800 $\mathrm{m}$ ) with rugged topography, the eastern side is generally low (approximately $1600 \mathrm{~m}$ ) and flat ${ }^{7}$. It is the administrative, commercial and industrial city of Kenya. Commercial and administrative activities are concentrated at the commercial business Centre while most of the industrial activities are located to the south Eastern part of Nairobi City. Nairobi is the most industrialized urban centre in Kenya and in East Africa in general $^{8}$. A total of 338 industries have been registered with the Directorate of Occupational Health and Safety (DOHS) ${ }^{8}$. Out of these, 123 are located in the industrial area, 53 in the central business district (CBD), 28 along Mombasa road and the rest are dispersed in other parts of the City ${ }^{8}$.

The sampling sites were chosen based on the fact that there are more human and economic activities in this County which attract large population which is considered to be the user of commercial plastic bottled drinking water. This is due to insufficient supply of clean drinking and domestic purpose water in the County. People in the offices prefer these bottled water due to affordability and availability in all packages; (that is in small quantities; portable and in large quantities).

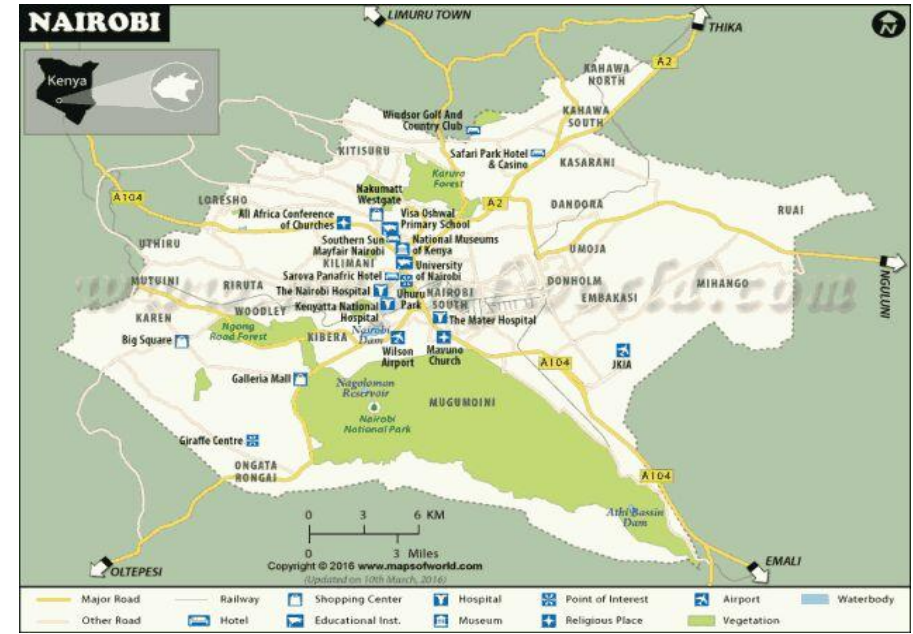

Figure1: A map showing the settlement distribution in Nairobi City

\section{2: Sampling}

The sampling of water was carried out 2019 and 2020. They were collected in triplicates from some major supermarkets in Nairobi City. They were then transported to the University of Nairobi laboratories for further analysis. They were then digested and stored in the fridge at $4^{\circ} \mathrm{C}$, and later the heavy metals were analysed using the AAS.

\section{3: The Heavy Metals Analysis}

$100 \mathrm{ml}$ of commercial bottled drinking water samples was measured in triplicates and digested in $10 \mathrm{ml}$ aqua regia mixture - (concentrated hydrochloric and nitric acids), $(\mathrm{HCl}$ : $\mathrm{HNO}_{3}$, both of analar grade from sigma- adrich chemicals) in the ratio of $3: 1$ and $1 \mathrm{ml}$ of per - chloric acid (Fisher scientific ltd) in conical flasks using hot plate for $21 / 2$ hours at $65{ }^{\circ} \mathrm{C}$. All the samples were cooled and filtered into $50 \mathrm{ml}$ volumetric flasks using Whatman No. 1 filter papers and made up to the volume with double distilled water. Then each sample was emptied in a specimen bottle rinsed with nitric solution in the ratio of 1:1 with distilled water and preserved in fridge awaiting AAS analysis. Calibration standards for each metal over the desired range were prepared by pipetting aliquots of the $100 \mathrm{mg} / \mathrm{l}$ standard solution into a series of volumetric flasks $(50 \mathrm{ml}), 1 \mathrm{ml}$ of concentrated nitric acid was added to each flask and diluted to the mark. The AAS was then switched on and appropriate hollow cathode lamp was selected and lamp current adjusted to the value recommended. The wavelength was fine-tuned and beam aligned whenever any metal was being analyzed. Using the lowest concentration of the standards, the AAS gain setting was optimized then the air valve was opened followed by the acetylene gas valve and ignited.

The samples, standards and blank were aspirated into the flame of AAS equipped with the appropriate hollow cathode lamp and operating wavelengths of $\mathrm{Sb}, \mathrm{Cd}, \mathrm{Cr}, \mathrm{Cu}, \mathrm{Mn}$ and $\mathrm{Pb}$ which are $228.8 \mathrm{~nm}, 357.9 \mathrm{~nm}, 324.7 \mathrm{~nm}, 279.5 \mathrm{~nm}$ and $218 \mathrm{~nm}$ respectively. Absorbance values for each standard and sample were recorded and calibration graphs were constructed 
by plotting absorbance against concentration. Finally, the concentrations were calculated from the regression lines obtained for each metal. These concentrations were compared to the standard acceptable and permissible concentration by NEMA, KEBs and WHO.

\section{5: Analysis of the physico-chemical parameters}

\subsection{1: Determination of $p H$}

In this case a $\mathrm{pH}$-meter with an accuracy that gave a reading within $\pm 0.1 \mathrm{pH}$ unit, and a glass electrode that produced a potential varying linearly with $\mathrm{pH}$ of solution in which it was immersed was used. $50 \mathrm{ml}$ of sample was drawn into a $50 \mathrm{ml}$ beaker and placed in a water bath at $25^{\circ} \mathrm{C}$. The $\mathrm{pH}$-meter instrument was switched on for at least 30 minutes, then it was calibrated with two standard buffer solutions of $\mathrm{pH} 10$ and 4.0 before the measurements were done. Then the $\mathrm{pH}$ values of the four samples were read by inserting the $\mathrm{pH}$ into the sample and the stable readings were finally recorded.

\subsection{2: Determination Electrical Conductivity}

$50 \mathrm{ml}$ of sample was drawn from the sampling container into a $250 \mathrm{ml}$ beaker and placed in a water bath at $25^{\circ} \mathrm{C}$. The instrument and cell was calibrated using $0.005 \mathrm{M} \mathrm{KCl}$ solution (conductivity $=654 \mu \mathrm{mho} \mathrm{cm}^{-1}$ ) before measurement. The electrode was rinsed by washing with distilled water after calibration and then dipped into the sample and reading were then recorded.

\subsection{3: Determination of TDS}

The TDS was obtained by multiplying the electrical conductivity value of the same sample by a known factor (0.7). The meter used allows a selection of a conversion ratio in the range of 0.4 to 1.0. The ratio varies with the application, but is typically set between 0.5 and 0.7 . The TDS values were therefore presented in $\mathrm{mg} / \mathrm{l}$.

\section{RESULTS AND DISCUSSIONS}

\subsection{The detection limits and equations of the calibration curves}

The levels of $\mathrm{Sb}, \mathrm{Cd}, \mathrm{Cr}, \mathrm{Mn}, \mathrm{Cu}, \mathrm{Pb}$ and $\mathrm{Zn}$ in the bottled drinking water samples obtained from various supermarkets in Nairobi County that were determined in triplicates using computerized AA-7000 Shimadzu Atomic Absorption spectrophotometer, are reported in this Chapter. The validity of the atomic absorption spectroscopy (AAS) results was assessed by determination of the detection limits of the heavy metals under analysis. This is used to confirm that the method is of good precision and accuracy. The limits of detection, the correlation coefficients, and the equations of the calibration curves for the determination levels of metals ions in the water samples using AAS are also captured in this Chapter.

Tablelindicates that the correlation coefficients of all calibration curves were $\geq 0.999$, which shows that there was a very high positive linear correlation between the concentration and the absorbance. The method detection limits for all the selected metals were $<0.1 \mu \mathrm{g} / \mathrm{ml}$ (Table 1) indicating that the method is applicable for the determination of heavy metals at trace levels. The performance of AAS spectrophotometer used in this study was therefore good and reliable to allow for its use in the analysis of the selected heavy elements in the samples.

Table 1: Limits of detection, Correlation coefficients and Equations of the calibration curves for the metal ions analysed in the water samples

\begin{tabular}{|l|l|l|l|}
\hline Element & $\begin{array}{l}\text { Limits of detection } \\
(\mu \mathrm{g} / \mathrm{ml})\end{array}$ & $\begin{array}{l}\text { Correlation } \\
\text { coefficient } \\
\text { calibration curve }\end{array}$ & of \\
\hline $\mathrm{Sb}$ & 0.0016 & 0.9998 & $\mathrm{y}=0.2045 \mathrm{x}+0.0009$ \\
\hline $\mathrm{Cu}$ & 0.027 & 0.9998 & $\mathrm{y}=0.2357 \mathrm{x}+0.0025$ \\
\hline $\mathrm{Cd}$ & 0.008 & 0.9998 & $\mathrm{y}=0.7079 \mathrm{x}+0.009$ \\
\hline $\mathrm{Cr}$ & 0.03 & 0.9990 & $\mathrm{y}=0.4337 \mathrm{x}+0.0005$ \\
\hline $\mathrm{Zn}$ & 0.02 & 0.9999 & $\mathrm{y}=0.4669 \mathrm{x}+0.0022$ \\
\hline $\mathrm{Pb}$ & 0.017 & 0.9998 & $\mathrm{y}=0.7169 \mathrm{x}+0.0013$ \\
\hline $\mathrm{Mn}$ & 0.05 & 0.9990 & $\mathrm{y}=0.342+0.004$ \\
\hline & & & \\
\hline
\end{tabular}

3.2 The Concentration of metal ion residues in the bottled drinking water

The mean concentration levels of $\mathrm{Sb}, \mathrm{Cd}, \mathrm{Cr}, \mathrm{Mn}, \mathrm{Cu}, \mathrm{Pb}$ and $\mathrm{Zn}$ in the bottled drinking water samples were as shown in the Table 2, which were presented in terms of mean and standard deviation (error). These concentrations were obtained from the calibration curve by calculations using their respective regression lines. For privacy purposes the seven brands of the water samples were lebelled as Sample A, B, C, D, E, F, and $\mathrm{G}$.

Table 2: Heavy metal concentration in the drinking water samples in $(\mathrm{mg} / \mathrm{g})$

\begin{tabular}{|c|c|c|c|c|c|c|c|}
\hline $\begin{array}{l}\text { Sample } \\
\text { Pararneter }\end{array}$ & A & B & C & D & $E$ & F & G \\
\hline $\mathrm{Cd}$ & BDL & $\mathrm{BDL}$ & BDL & BDL & BDL & BDL & BDL \\
\hline $\mathrm{Cr}$ & BDL & BDL & BDL & BDL & $0.66 \pm 0.03$ & BDL & BDL \\
\hline $\mathrm{Cu}$ & $0.05 \pm 0.01$ & $0.02 \pm 0.03$ & BDL & $0.03 \pm 0.03$ & BDL & BDL & BDL \\
\hline Mn & BDL & BDL & BDL & BDL & BDL & BDL & $0.93 \pm 0.53$ \\
\hline $\mathrm{Pb}$ & $0.003 \pm 0.01$ & BDL & BDL & BDL & BDL & $0.32 \pm 0.19$ & $0.14 \pm 0.07$ \\
\hline sb & BDL & BDL & BDL & BDL & BDL & BDL & BDL \\
\hline $\mathrm{Zn}$ & BDL & BDL & BDL & BDL & BDL & BDL & BDL \\
\hline
\end{tabular}

Key: $\mathrm{BDL}=$ Below Detection Limit

Table 3: The permissible residue limits of metal ions stipulated by various bodies in $(\mathrm{mg} / \mathrm{g})$

\begin{tabular}{|l|l|l|l|l|l|l|l|}
\hline \multicolumn{1}{|c|}{ Metal type } & $\mathrm{Cr}$ & Mn & $\mathrm{Pb}$ & $\mathrm{Cd}$ & $\mathrm{Zn}$ & $\mathrm{Sb}$ & $\mathrm{Cu}$ \\
\hline Kody & & & & & & & \\
\hline WHO & 0.05 & 0.1 & 0.05 & 0.005 & 5.0 & - & 0.1 \\
\hline
\end{tabular}




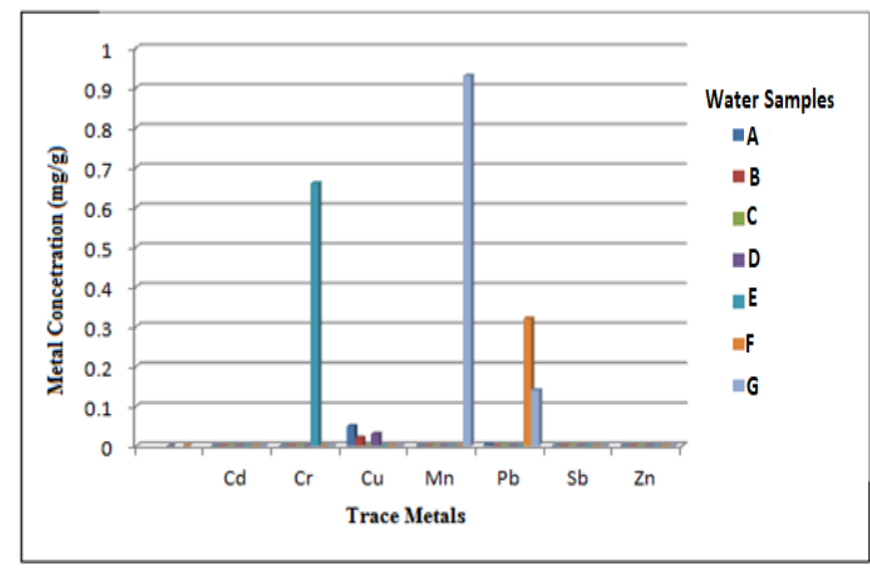

Figure 2: Bar graph showing the concentration of various heavy metals detected.

As can be observed from Table 2, antimony, cadmium and Zinc residue levels were all below the detectable limit in all the seven brands of water samples that were analysed in the current study. This indicates that, there may be some improved methods of monitoring the presence of the said trace metals in situ, during the purification process of the drinking water that successfully maintain their standard levels. On other hand, Copper residues were only detected in three brands of drinking water with levels of $0.05 \pm 0.01 \mathrm{mg} / \mathrm{l}$, $0.02 \pm 0.03 \mathrm{mg} / \mathrm{l}$ and $0.03 \pm 0.03 \mathrm{mg} / \mathrm{l}$ (Table 2), which were below the set standards by WHO as shown in Table 3. The residues of lead metals were detected in three brands of water also with concentrations of $0.003 \pm 0.01 \mathrm{mg} / 1,0.32 \pm 0.19 \mathrm{mg} / \mathrm{l}$ and $0.14 \pm 0.07$ (Table 2). These metal ions (copper and lead) may have entered into the drinking water through the contaminations from the bottling process and from the corroded metal pipes used for delivering and bottling drinking water.

\subsection{Results for the physico-chemical parameters}

The $\mathrm{pH}$, Electrical conductivity and Total Dissolved Solids (TDS) was done in only four samples and their results are shown in Table 4. Table 5 shows the Acceptable set limits by some international bodies for the analysed physicochemical parameter in the current study.

Table 4:physico-chemical parameters levels in water samples

\begin{tabular}{|c|l|l|l|}
\hline Water Brands & Parameters & $\begin{array}{l}\text { TDS } \\
\text { in mgl }\end{array}$ & $\begin{array}{l}\text { Electrical } \\
\text { Conductivity } \\
\text { in } \mu \text { S/cm }\end{array}$ \\
\hline A & $6.72 \pm 0.15$ & $26.80 \pm 0.50$ & $74.50 \pm 0.05$ \\
\hline B & $6.63 \pm 0.10$ & $63.10 \pm 0.33$ & $125.70 \pm 0.70$ \\
\hline C & $7.03 \pm 0.23$ & $100.7 \pm 0.08$ & $89.40 \pm 0.93$ \\
\hline D & $7.32 \pm 0.01$ & $98.40 \pm 0.19$ & $197.70 \pm 0.02$ \\
\hline
\end{tabular}

Table 5: Acceptable set limits by some international bodies

\begin{tabular}{|c|c|c|c|}
\hline Body & pH & TDS & Electrical Conductivity \\
\hline NEMA & 65.58 .5 & $1500 \mathrm{mg} / \mathrm{d}$ & $25-2500 \mathrm{\mu} / \mathrm{s}$ \\
\hline KEBS & 6.09 .90 & $1500 \mathrm{mg} / \mathrm{|}$ & $30.2500 \mathrm{\mu s} / \mathrm{cm}$ \\
\hline WHO & 6.29 .4 & $1500 \mathrm{mg} / \mathrm{d}$ & $26 .-2500 \mathrm{\mu s} / \mathrm{cm}$ \\
\hline
\end{tabular}

\subsubsection{The $\mathrm{pH}$ of the Samples.}

$\mathrm{pH}$ is the measure of hydrogen ion concentration in water. The values above 7.0 shows alkalinity of the water sample while those below 7.0 indicates acidity of the sample. The data in Table 5 shows various $\mathrm{pH}$ values of the four different sampled bottled drinking water and comparison of these data to those from some international bodies is shown in Table 5.

\subsubsection{Comparison and Interpretation pH Results}

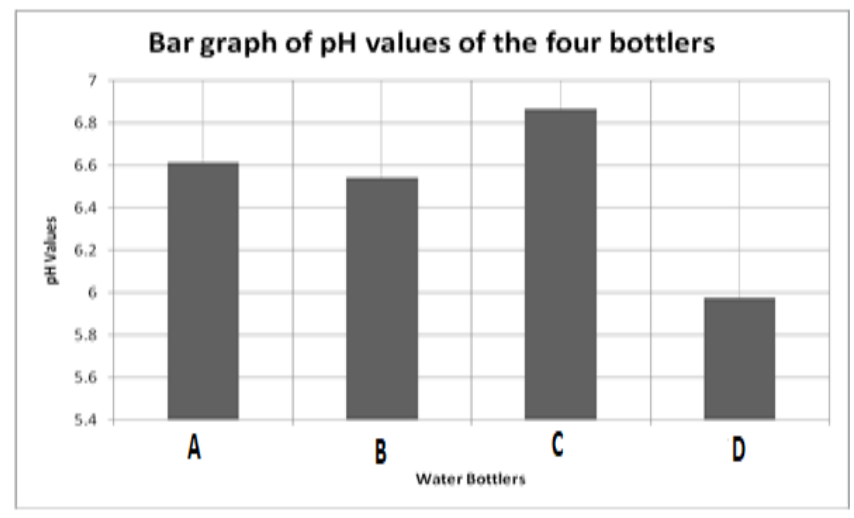

Figure 3: $\mathrm{pH}$ values of the four water samples

According to Figure 2 sample $\mathrm{C}$, showed the highest $\mathrm{pH}$ value and sample $\mathrm{D}$ indicated the lowest $\mathrm{pH}$ value. The $\mathrm{pH}$ values of all the water samples, $\mathrm{A}, \mathrm{B}$ and $\mathrm{C}$ were well within the range of drinking water standards according to NEMA, KEBS and WHO which is $6.5-9.4$ (Table 5) for all, while that of the brand $\mathrm{D}$ were below the minimum limit of drinking water standards $(6.5-8.5)$. Therefore, the $\mathrm{pH}$ value of sample D shifted to acidity indicating that the metal ions in it are suspended thus water may change the taste.

The acidity $\mathrm{pH}$ could be as a result of methods used in the bottlers in that the $\mathrm{pH}$ is not regularly monitored. Also corroded water pipes delivering water to the plant may be the plausible cause of these low $\mathrm{pH}$ and the mode of treatment of water before packing in bottles.

\subsubsection{The Total dissolved solids (TDS) in the water Samples}

TDS is defined as the matter undissolved in water in general ${ }^{9}$. According to the current study, the TDS values obtained ranged between $26.80 \pm 0.50$ and $100.7 \pm 0.08 \mathrm{mg} / \mathrm{l}$ as can be observed in Table 4. The mean values were within the 
acceptable, permissible limits by NEMA, KEBS and WHO of $1,500 \mathrm{mg} / \mathrm{l}($ Table 4.5$)$

\subsubsection{Electrical Conductivity (EC)}

Conductivity is the degree of waters ability to allow electric flow and is directly related to the concentration of ions in the water. High levels of ions in water leads to high conductivity and the opposite is vice versa ${ }^{\mathbf{1 0}}$. The electrical conductivity in this study was found to range between $74.50 \pm 0.05$ and197.70 \pm 0.020 (Table 4). The limits were within the allowed limits of $25-2500 \mu \mathrm{S} / \mathrm{cm}$ standard levels stipulated by NEMA, KEBs and WHO (Table 5).

\section{CONCLUSION}

In conclusion, the objectives of this research project were achieved in that PET bottled drinking water samples were analyzed for metal ions using AAS and were detected in different levels. Concentration of metals such as Antimony, cadmium and Zinc were determined and found to be below detection limit, while the concentration of copper ions were below the permissible maximum levels stipulated by health organizations (KEBs and WHO) as can be observed in Table 4.3, implying that they are not in harmful levels. The levels for Manganese in sample $\mathrm{G}$ which was $0.93 \mathrm{mg} / \mathrm{g}$ was higher than the set levels by KEBs and WHO of $0.1 \mathrm{mg} / \mathrm{g}$ and 0.2 $\mathrm{mg} / \mathrm{g}$ respectively. On the other hand, the levels for Lead in samples $F$ and $G$ of $0.32 \mathrm{mg} / \mathrm{g}$ and $0.14 \mathrm{mg} / \mathrm{g}$ respectively were found to be higher than the standard levels of $0.05 \mathrm{mg} / \mathrm{g}$ and $0.04 \mathrm{mg} / \mathrm{g}$ by KEBs and WHO respectively.

The levels of all the physico-chemical parameters analysed in this study including pH, TDS and Electrical Conductivity were within the range according to health organizations. Therefore, based on this study some brands of PET plastic bottled drinking water sold in Nairobi County may not be very safe for consumption by the residence. Industrial failure to regularly monitor the quality of drinking bottled water brands may lead to accumulation of contaminants that are beyond the permissible levels. This may eventually have tremendous effects on the lives of the consumers.

\section{REFERENCE}

[1] Ahmad A., Mushrifah I., Othman MS., (2009). Water quality and heavy metal concentrations in sediment of Sungai Kelantan, Malaysia. Page 435-442.

[2] Bach C., Dauchy X., Chignon M.C., and Entiene S., (2012). Commercial compounds and toxicological assessments of drinking water stored in polyethylene terephthalate (PET) bottles.

[3] World Bank, (2015). World Development Indicators (Washington, DC: The World Bank).

[4] Kenya National Bureau of Statistics (KNBS) (2020). Kenya 2019 Population and Housing census. Analytical report on Population Dynamics. Ministry of Planning. Nairobi.

[5] WHO (2003). Antimony in drinking water, Background documents for preparation of WHO guidelines for drinking water quality, Geneva.

[6] Mitullah W., (2003). Understanding Slums:Case Studies for the Global Report on Human Settlements 2003: The Case of Nairobi, Kenya, UN-habitat, Nairobi.

[7] Saggerson E.P., (1991). Geology of the Nairobi Area. Degree Sheet 51, NE QUARTER, Mines and Geology Department, English Press, Nairobi, Kenya.

[8] Japan International Cooperation Agency (JICA), 2004). Annual Report Summary.html.

[9] Navneet, Kumar, D. K. Sinha, (2010), Drinking water quality management through correlation studies among various physicochemical parameters: A case study, International Journal of Environmental Sciences, 1(2), pp 253-259.

[10] Alnes, I. B., Barbosa, J., Iden, P., \&Sjøberg, A. G. (2014). Water quality of Sælenvatnet. A guide to the use of biota, sediments and water in Environ mental monitoring, 2007: Edited by Deborah Chapman published by Taylor \& Francis group New York and London, $2^{\text {nd }}$ Edition. American Public Health Association (APHA), 1992: American Water Works Association (AWWA) and Water Pollution Control Federation (WPCF), Washington, D.C. 